\title{
Formations of Oligopeptides from Dipeptides by the Protease from Streptomyces cellulosae
}

\author{
Tetsuo Muro, Yoshio Tominaga and Shigetaka-OKada \\ Osaka Municipal Technical Research Institute, \\ 6-50 Morinomiya 1-chome, Joto-ku, Osaka 536, Japan
}

Received October 7, 1983

\begin{abstract}
The protease from Streptomyces cellulosae formed more turbidity in a $16 \%$ soybean protein hydrolysate in the initial stage of the reaction than $\alpha$-chymotrypsin did, when the proteolytic activity of the protease was same as that of $\alpha$-chymotrypsin. In highly concentrated solutions $(2.5 \%)$ of various dipeptides, oligopeptides were produced by condensation by the protease. The oligopeptides formed were (L-Leu-Gly) ${ }_{2}$ and (L-Leu-Gly) ${ }_{3}$ from L-Leu-Gly, (L-Phe-L-Val) $)_{2}$ from L-Phe-LVal, (L-Val-L-Phe) ${ }_{2}$ and (L-Val-L-Phe) $)_{3}$ from L-Val-L-Phe, and (L-Leu-L-Met) ${ }_{2}$ and (L-Leu-L-Met) ${ }_{3}$ from L-Leu-L-Met.
\end{abstract}

The reverse reaction of proteases, i.e., peptide bond synthesis, can also be catalyzed by the same enzyme, as was first demonstrated by Bergmann and Fraenkel-Conrat ${ }^{1)}$ in 1937 with papain which catalyzed amide (anilide) bond synthesis. Since then, many reports have been appeared on reverse reactions of proteases, for instance, semi-synthesis of human insulin from porcine insulin, ${ }^{2 \sim 4)}$ semi-synthesis of an angiotensin analogue, ${ }^{5)}$ or plastein formation. ${ }^{6 \sim 8)}$ However, proteases used for peptide synthesis are enzymes obtained mainly from animals and plants, and the equilibrium of the reaction lies toward hydrolysis. We are interested in screening microorganisms which secrete proteases having strong activity in peptide synthesis.

The protease from Streptomyces cellulosae formed more turbidity in a $16 \%$ soybean protein hydrolysate in the initial stage of the reaction than $\alpha$-chymotrypsin did, so this protease presumably catalyzes the condensation or the transpeptidation reaction of peptides in highly concentrated peptide solutions. This study deals with the formations of oligopeptides by the protease from $S$. cellulosae, using high concentrations of various dipeptide solutions as the substrates.

\section{MATERIALS AND METHODS}

Materials. Gly, L-Phe, and L-Leu-Gly were purchased from the Nakarai Chemical Company. All the other peptides were purchased from the Sigma Chemical Company. The protease from Streptomyces cellulosae was purified to homogeneity on electrophoretic analysis as described in our previous report. ${ }^{9)}$

Assay of the turbidity-forming activity. Turbidity formation by the protease was measured according to the method described in our previous report. ${ }^{9)}$

Estimation of molecular weight of oligopeptides by gel filtration. A column of Bio-Gel P-2 (400 mesh) washed with $0.01 \mathrm{M}$ phosphate buffer $(\mathrm{pH} 7.0)$ containing $0.1 \mathrm{M}$ $\mathrm{NaCl}$, was used. Gly and standard peptides (carbobenzoxy-L-Pro-L-Leu-Gly, hexa-Gly, penta-Gly, tetra-Gly, tri-Gly, and di-Gly) were applied on the Bio-Gel $\mathrm{P}-2$ column $(1.7 \times 75 \mathrm{~cm})$. Blue dextran was used to determine the void volume of the column. Fractions of $1.5 \mathrm{ml}$ were collected at flow rate of $8.4 \mathrm{ml} / \mathrm{hr}$.

\section{Analytical methods.}

(i) $N$-Terminal amino acid analysis. The $\mathrm{N}$-terminal amino acids of peptides were analyzed by the method of Sanger and Thompson. ${ }^{10)}$ The dinitrophenyl peptides were hydrolyzed in $6 \mathrm{~N} \mathrm{HCl}$ in an evacuated tube for $16 \mathrm{hr}$ at $105^{\circ} \mathrm{C}$. The dinitrophenyl-amino acids (DNP-amino acids) were identified by two-dimensional thin-layer chromatography (TLC) in the solvent systems of toluene-pyridine-2chloroethanol $(30: 9: 18)$ treated with $18 \mathrm{ml}$ of $0.8 \mathrm{~N}$ ammonia water, and benzene-pyridine-acetic acid $(80: 20: 2){ }^{11)}$ In quantitative analysis of DNP-amino acids, the silica gel powder at the DNP-amino acid 
position was scratched off of the TLC plate and extracted in $4 \mathrm{ml}$ of $1 \% \mathrm{NaHCO}_{3}$. Then the optical density of the extract was measured at $360 \mathrm{~nm}$ with a Shimadzu UV210A spectrophotometer.

(ii) C-terminal amino acid analysis. The C-terminal amino acids of peptides were analyzed by the method of Akabori. ${ }^{12)}$ The dried sample was dissolved in $0.5 \mathrm{ml}$ of anhydrous hydrazine, and was hydrolyzed in an evacuated tube for $8 \mathrm{hr}$ at $100^{\circ} \mathrm{C}$. After opening the tube, the sample was lyophilized and then analyzed using a Hitachi KLA-5 automatic amino acid analyzer.

(iii) Amino acid analysis. Hydrolysis of peptides was carried out in $6 \mathrm{~N} \mathrm{HCl}$ in an evacuated tube for $20 \mathrm{hr}$ at $110^{\circ} \mathrm{C}$. Only products from L-Leu-L-Met were oxidized by performic acid and then hydrolyzed. The amino acids produced were analyzed with a Hitachi KLA-5 automatic amino acid analyzer.

Estimation of retention constants of oligopeptides by reverse phase high performance liquid chromatography. Retention constants of oligopeptides were determined by the method of Molnár and Horváth. ${ }^{14)}$ A $5-\mu \mathrm{m}$ LiChrosorb RP-18 column $(0.5 \times 25 \mathrm{~cm})$ was used. The flow-rate and column temperature were $2 \mathrm{ml} / \mathrm{min}$ and $70^{\circ} \mathrm{C}$, respectively. The mobile phase was $0.5 \mathrm{M}$ perchloric acid and the mobile phase modifer was acetonitrile. The concentration of the mobile phase modifer was increased linearly from 0 to $100 \%(\mathrm{v} / \mathrm{v})$ over $60 \mathrm{~min}$. The elution pattern was monitored by absorption at $220 \mathrm{~nm}$. L-Phe and standard peptides (di-Phe, tri-Phe, tetra-Phe, and penta-Phe) were applied on the above column. In Fig. 1, the retention times observed were plotted against $\ln \left(1+\sum_{j} D_{j} n_{i j}\right)$, where $D_{j}$ is the calculated retention con-

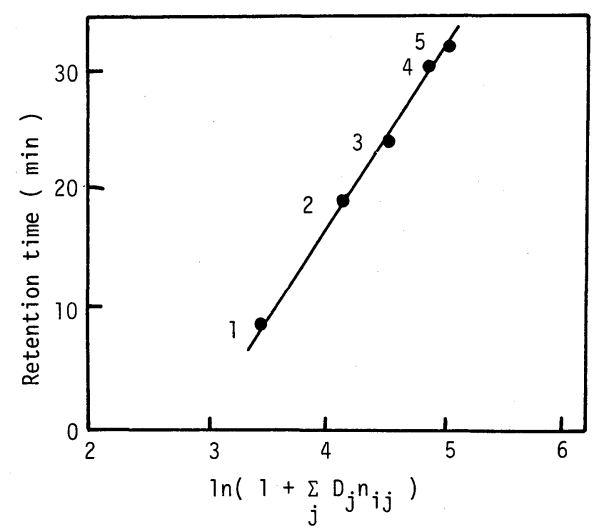

FIG. 1. Relationship between Retention Time and $\ln \left(1+\sum_{j} D_{j} n_{i j}\right)$.

The observed retention times of samples were plotted against $\ln \left(1+\sum_{j} D_{j} n_{i j}\right)$, where $D_{j}$ was the calculated retention constant. ${ }^{13)} 1$, phenylalanine ; 2 , di-phenylalanine; 3, tri-phenylalanine; 4 , tetra-phenylalanine; 5 , pentaphenylalanine. stant of amino acid $j$ by unweighted curve fitting, and $n_{i j}$ is the number of residues of amino acid $j$ in peptide $i^{15}$ )

Paper chromatography. Paper chromatography was carried out on Tōyō No. 50 filter paper $(40 \times 40 \mathrm{~cm})$ using $n$ butanol, acetic acid and water $(4: 1: 2, \mathrm{v} / \mathrm{v})$ as a solvent system by the ascending method. The amino acids and peptides on the paper chromatogram were detected with ninhydrin reagent.

Digestions of $P_{1}$ and $P_{2}$ by carboxypeptidase $A$ (CPase $A$ ). In order to determine the $\mathrm{C}$-terminal amino acids of the products $\left(\mathrm{P}_{1}\right.$ and $\left.\mathrm{P}_{2}\right)$ from L-Leu-Gly, they were hydrolyzed by $\mathrm{CPase} \mathrm{A}$ at $\mathrm{pH} 7.5 .{ }^{13)}$ After the appropriate time of incubation at $37^{\circ} \mathrm{C}$, the reaction mixture was subjected to paper chromatography. Each spot stained by ninhydrin reagent was cut out and the content of each fraction was determined by the optical density at $570 \mathrm{~nm}$ with a Shimadzu UV-210A spectrophotometer.

\section{RESULTS}

\section{Actions of the protease on high concentrations} of various dipeptides

Each $5 \%$ dipeptide solution $(100 \mu \mathrm{l})$ adjusted to $\mathrm{pH} 7.0$ was incubated with the protease (100 $\mu$ l, turbidity-forming activity, $26.4 \mathrm{U}$ ). After 0,3 , and $8 \mathrm{hr}$ incubations at $40^{\circ} \mathrm{C}$, the reaction products were analyzed by paper chromatography. One or two unknown spots which were stained with ninhydrin were observed in each case. These results are summarized in Table I. On the other hand, strong turbidity formation could be observed using L-Phe-L-Val, L-Val-L-Phe, and L-Leu-L-Met as substrates. However, such phenomena were not observed even in $8 \mathrm{hr}$ incubation of the other dipeptides.

\section{Action of the protease on L-Leu-Gly}

The paper chromatogram of products from L-Leu-Gly by the protease is shown in Fig. 2. Two unknown spots $\left(\mathrm{P}_{1}\right.$ and $\left.\mathrm{P}_{2}\right)$ which were stained by ninhydrin were observed, along with the hydrolysis products (Leu and Gly). The areas around each stained region $\left(\mathrm{P}_{1}\right.$ and $\mathrm{P}_{2}$ ) were cut out, eluted with water and then lyophilized. The preparations of $\mathrm{P}_{1}$ and $\mathrm{P}_{2}$ were homogeneous on paper chromatography and used in following analytical experiments. The yields of $\mathrm{P}_{1}$ and $\mathrm{P}_{2}$ from $500 \mathrm{mg}$ of L-LeuGly after $8 \mathrm{hr}$ of incubation were $1.2 \mathrm{mg}$ and 
Table I. Actions of the Protease on High Concentrations of Various Dipeptides

\begin{tabular}{lcc}
\hline \multicolumn{1}{c}{ Dipeptides } & $\begin{array}{c}\text { No. of } \\
\text { unknown } \\
\text { spots }^{a}\end{array}$ & Turbidity $^{b}$ \\
\hline L-Phe-L-Leu-NH & \\
Gly-L-Leu & 0 & - \\
Gly-L-Ile & 2 & - \\
Gly-L-Phe & 1 & - \\
L-Ala-L-Leu & 2 & - \\
L-Leu-Gly & 1 & - \\
L-Leu-L-Ala & 2 & - \\
L-Leu-L-Ser & 1 & - \\
L-Leu-L-Val & 2 & - \\
L-Phe-L-Val & 1 & + \\
L-Val-L-Phe & 1 & + \\
L-Leu-L-Met & 1 & + \\
\hline
\end{tabular}

a No. of unknown spots means the numbers of spots detected from paper chromatography, aside from hydrolytic products (amino acids) and dipeptides as substrates.

$b$ This column shows that the phenomenon of turbidity formation was observed or not within $1 \mathrm{hr}$ of incubation by the protease from $S$. cellulosae.

\section{$22.5 \mathrm{mg}$, respectively.}

Estimation of molecular weights of $P_{1}$ and $P_{2}$

The molecular weights of $\mathrm{P}_{1}$ and $\mathrm{P}_{2}$ were estimated to be 390 and 510 from the elution patterns by gel filtration on a Bio-Gel P-2 column (Fig. 3).

\section{Amino acid compositions and $N$-terminal and $C$ - terminal amino acids of $P_{1}$ and $P_{2}$}

By amino acid analysis, the molar ratios of Leu and Gly were $1: 1.1$ in $\mathrm{P}_{1}$ and $1: 1.0$ in $\mathrm{P}_{2}$, respectively, as shown in Table II. The Nterminal and C-terminal amino acids of $\mathrm{P}_{1}$ and $\mathrm{P}_{2}$ were identified to be Leu and Gly, respectively. The amino acid composition of the residues in which the DNP-amino acid was removed by ethyl ether extraction was analyzed (Table II). The ratio of amino acid composition of the residue prepared from $\mathrm{P}_{1}$ was Leu and Gly $(1: 1.9)$. By considering the content of DNP-Leu obtained from $\mathrm{P}_{1}$ in $\mathrm{N}$ terminal amino acid analysis, the ratio of DNP-amino acid and amino acid composition of the residue was DNP-Leu, Leu and Gly

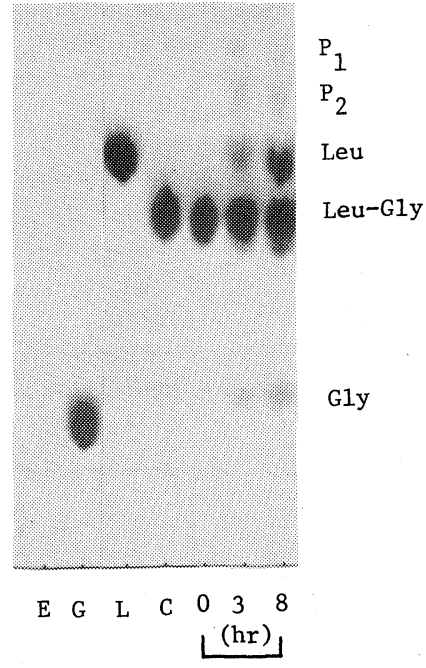

FIG. 2. Paper Chromatogram of Products from $2.5 \% \mathrm{~L}-$ Leu-Gly by the Protease.

E, the protease from S. cellulosae; G, glucine; L, leucine; C, $2.5 \%$ L-Leu-Gly incubated without enzyme for $8 \mathrm{hr}$ at $40^{\circ} \mathrm{C} ; \mathrm{P}_{1}, \mathrm{P}_{2}$, unknown spots stained with ninhydrin reagent.

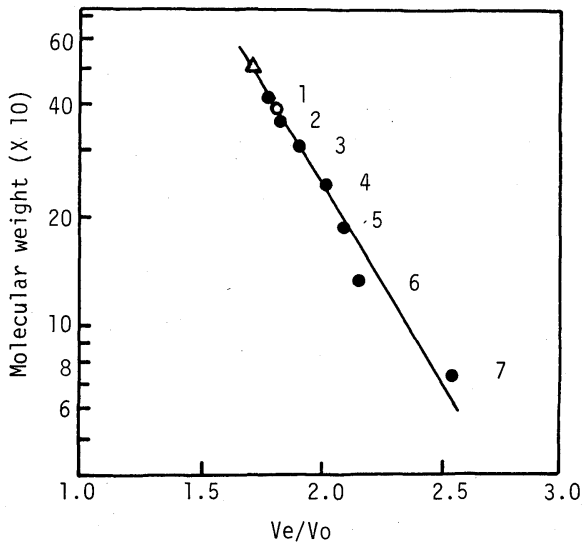

FIG. 3. Molecular Weights of Oligopeptides by Gel Filtration on a Bio-Gel P-2 Column.

O, $\mathrm{P}_{1} ; \triangle, \mathrm{P}_{2} .1$, carbobenzoxy-L-Pro-L-Leu-Gly; 2 , hexa-glycine; 3 , penta-glycine; 4 , tetra-glycine; 5 , triglycine; 6 , di-glycine; 7 , glycine; $V e$, elution volume; $V o$, void volume of the column.

$(1.0: 1: 1.9)$. With the same method, the ratio obtained from $\mathrm{P}_{2}$ was DNP-Leu, Leu and Gly $(0.9: 2: 3.2)$.

Hydrolyses of $P_{1}$ and $P_{2}$ by CPase $A$

Figure 4(a) shows that almost identical con- 
Table II. Amino Acid Compositions and N- And C-Terminal Amino Acids OF $\mathrm{P}_{1}$ AND $\mathrm{P}_{2}$ Produced from L-Leu-Gly by the Protease

\begin{tabular}{ccccc}
\hline Product & $\begin{array}{c}\text { Molar ratio of } \\
\text { amino acid }\end{array}$ & & $\begin{array}{c}\text { Treatment with FDNB }^{a} \\
\text { Molar ratio of amino acids }\end{array}$ & $\begin{array}{c}\text { Hydrolysis by } \\
\text { hydrazine }\end{array}$ \\
\cline { 2 - 3 } & Leu:Gly & DNP-Leu: Leu : Gly & Gly \\
\hline $\mathrm{P}_{1}$ & $1: 1.1$ & $1.0: 1: 1.9$ & Gly \\
\hline
\end{tabular}

a FDNB, 1-fluoro-2,4-dinitrobenzene.

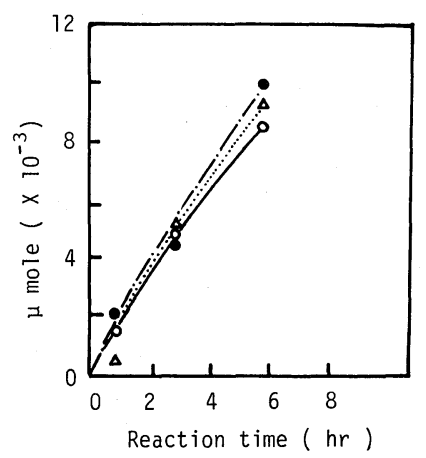

(a)

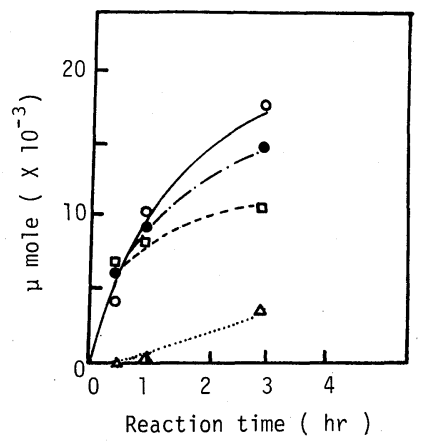

(b)

FIG. 4. Hydrolyses of Products $\mathrm{P}_{1}$ and $\mathrm{P}_{2}$ by Carboxypeptidase $\mathrm{A}$.

(a) $\mathrm{P}_{1}$ was digested by CPase $\mathrm{A}$ for 1,3 , and $6 \mathrm{hr}$ at $40^{\circ} \mathrm{C}$.

(b) $\mathrm{P}_{2}$ was digested by CPase $\mathrm{A}$ for $0.5,1$, and $3 \mathrm{hr}$ at $40^{\circ} \mathrm{C} . \mathrm{O}-\mathrm{O}$, leucine ;

L-Leu-Gly; $\square----\square, \mathrm{P}_{1}$.

tents of Leu, Gly, and Leu-Gly were simultaneously released from $\mathrm{P}_{1}$ by CPase A digestion. Figure 4(b) also shows that almost identical contents of Leu, Gly, and $\mathrm{P}_{1}$ were simultaneously released from $\mathrm{P}_{2}$ by CPase A digestion in the initial stage of the reaction, followed by the production of Leu-Gly.

\section{Actions of the protease on L-Phe-L-Val, L-Val- $L$-Phe and L-Leu-L-Met}

$1 \mathrm{ml}$ of the protease solution (turbidityforming activity, $264 \mathrm{U}$ ) was added to $1 \mathrm{ml}$ of $5 \%$ dipeptide solution (L-Phe-L-Val, L-Val-LPhe or L-Leu-L-Met) adjusted to $\mathrm{pH} 7.0$ at $40^{\circ} \mathrm{C}$. After $1 \mathrm{hr}$ of incubation, strong turbidity could be observed in each dipeptide solution. The reaction mixture $(20 \mu \mathrm{l})$ was subjected to paper chromatography (Fig. 5). The unknown spots $\left(P_{p}, P_{v}\right.$ and $\left.P_{L}\right)$ were observed from LPhe-L-Val, L-Val-L-Phe and L-Leu-L-Met on paper chromatograms, respectively, along with the spots of free amino acids produced by hydrolysis of the dipeptides.

Then $P_{p}, P_{v}$ and $P_{L}$ were separated from the reaction mixtures by centrifugation, washed sufficiently with ice-water, and dried to constant weight over $\mathrm{P}_{2} \mathrm{O}_{5}$ under reduced pressure. The $P_{p}, P_{v}$ and $P_{L}$ obtained were homogeneous on paper chromatography, and their $R f$ values were the same as those shown in Fig. 5. These homogeneous samples of $P_{p}, P_{v}$ and $P_{L}$ were used in the following experiments. The yields of $\mathrm{P}_{\mathrm{p}}, \mathrm{P}_{\mathrm{v}}$ and $\mathrm{P}_{\mathrm{L}}$ from $50 \mathrm{mg}$ of dipeptide were $15.3,8.3$ and $8 \mathrm{mg}$, respectively, with $3 \mathrm{hr}$ of incubation.

\section{Amino acid compositions and $N$-terminal and $C$ -} terminal amino acids of $P_{p}, P_{v}$ and $P_{L}$

The molar ratios of amino acid compositions of $\mathrm{P}_{\mathrm{p}}, \mathrm{P}_{\mathrm{v}}$ and $\mathrm{P}_{\mathrm{L}}$ were Phe and $\operatorname{Val}(1: 1)$ 


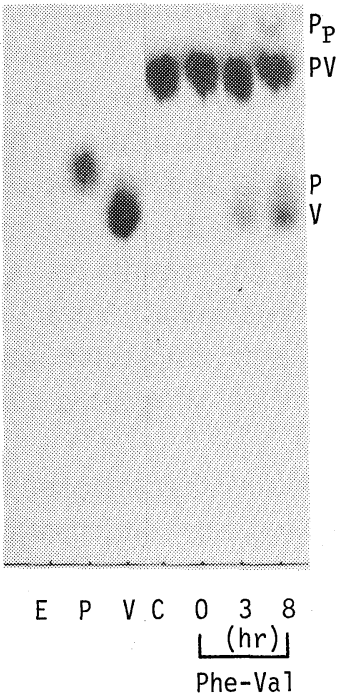

(a)

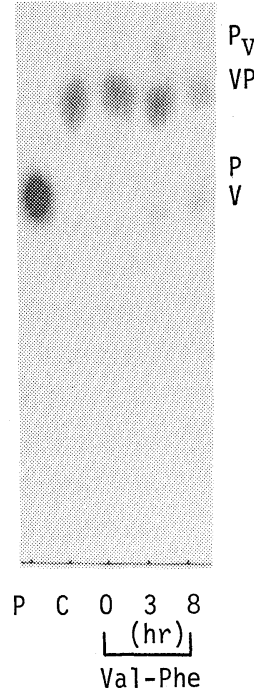

(b)

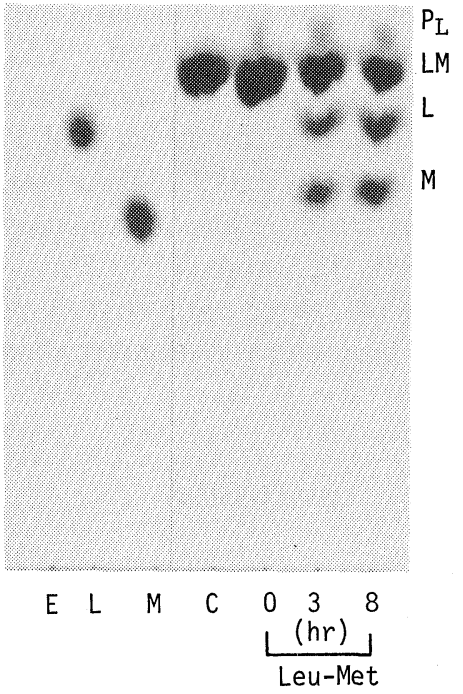

(c)

FIG. 5. Paper Chromatograms of Products $P_{p}, P_{v}$, and $P_{L}$ Produced from $2.5 \%$ Dipeptides by the Protease. (a) With L-Phe-L-Val (PV) as a substrate: E, the protease from $S$. cellulosae; $\mathrm{P}$, phenylalanine; V, valine ; $\mathrm{P}_{\mathrm{p}}$, unknown spot stained with ninhydrin reagent.

(b) With L-Val-L-Phe (VP) as a substrate: $P_{v}$, unknown spot stained with ninhydrin reagent.

(c) With L-Leu-L-Met (LM) as a substrate. L, leucine; $\mathrm{M}$, methionine; $\mathrm{P}_{\mathrm{L}}$, unknown spot stained with ninhydrin reagent.

C, $2.5 \%$ of each dipeptide incubated without enzyme for $8 \mathrm{hr}$ at $40^{\circ} \mathrm{C}$.

Table III. Amino Acid Compositions And N- AND

C-Terminal Amino Acids of $P_{p}, P_{v}$, AND $P_{P}$ Produced From Various Dipeptides BY THE PROTEASE

\begin{tabular}{cccc}
\hline Product & $\begin{array}{c}\text { Molar ratio of } \\
\text { amino acid }\end{array}$ & $\begin{array}{c}\text { Treatment } \\
\text { with FDNB }\end{array}$ & $\begin{array}{c}\text { Hydrolysis } \\
\text { by hydrazine }\end{array}$ \\
\hline & Phe: Val & Phe & Val \\
$\mathrm{P}_{\mathrm{p}}$ & $1.04: 1$ & Val & Phe \\
$\mathrm{P}_{\mathrm{v}}$ & $0.99: 1$ & & \\
& Leu $:$ Met & Leu & Met \\
$\mathrm{P}_{\mathrm{L}}$ & $1.01: 1$ & .
\end{tabular}

a FDNB: 1-fluoro-2,4-dinitrobenzene.

in both $P_{p}$ and $P_{v}$, and Leu and Met $(1: 1)$ in $P_{L}$. The N-terminal amino acids of $P_{p}, P_{v}$ and $P_{L}$ were Phe, Val and Leu, respectively. On the other hand, the C-terminal amino acids of $P_{p}$, $P_{v}$, and $P_{L}$ were Val, Phe and Met, respectively. These data are summarized in Table III.

Retention constants of $P_{p}, P_{v}$ and $P_{L}$

$\mathrm{P}_{\mathrm{p}}, \mathrm{P}_{\mathrm{v}}$ and $\mathrm{P}_{\mathrm{L}}$ were dissolved in $0.5 \mathrm{M}$ perchloric acid and applied on a LiChrosorb RP-
Table IV. Retention Constants of $P_{p}, P_{v}$ AND $P_{L}$

\begin{tabular}{|c|c|c|}
\hline \multicolumn{2}{|c|}{ Samples } & \multirow{2}{*}{$\begin{array}{l}\text { Retention constant } \\
\qquad \sum_{j} D_{j} n_{i j}\end{array}$} \\
\hline Substrate & Product & \\
\hline \multirow[t]{2}{*}{ L-Phe-L-Val } & & 38.8 \\
\hline & $P_{p}$ & 90.0 \\
\hline \multirow{2}{*}{ L-Val-L-Phe } & & 38.8 \\
\hline & $\mathrm{P}_{\mathrm{v} 1}$ & 89.9 \\
\hline \multirow{4}{*}{ L-Leu-L-Met } & $\mathrm{P}_{\mathrm{v} 2}$ & 111.2 \\
\hline & & 40.9 \\
\hline & $P_{L 1}$ & 82.5 \\
\hline & $\mathrm{P}_{\mathrm{L} 2}$ & 111.1 \\
\hline
\end{tabular}

a These values were calculated from the calibration curve in Fig. 1.

18 column. The retention constant $\left(\sum_{j} D_{j} n_{i j}\right)$ of $\mathrm{P}_{\mathrm{p}}$ was calculated to be 90.0 from the calibration curve in Fig. 1, as its retention time was observed to be $24.33 \mathrm{~min}$. This value of the retention constant was about twice that (38.8) of L-Phe-L-Val. On the other hand, two retention times ( 24.43 and $27.5 \mathrm{~min}$ ) were observ- 
ed from $\mathrm{P}_{\mathbf{v}}$. Therefore, retention constants of $P_{v}$ were calculated to be 89.9 and 111.2. These values were about twice or three times that (38.8) of L-Val-L-Phe. In the case of $\mathrm{P}_{\mathrm{L}}$, two retention times (23.07 and $27.54 \mathrm{~min}$ ) were also observed. Therefore, retention constants were calculated to be 82.5 and 111.1. These values were also twice or three times that (40.9) of LLeu-L-Met. These data are summarized in Table IV.

\section{DISCUSSION}

In our previous report, ${ }^{9}$ ) we showed that the protease from $S$. cellulosae forms much turbidity from soybean protein hydrolysate in the initial stage of the reaction. The present study investigated the actions of the protease on various dipeptides at high concentrations. As a result, it was recognized that unknown products stained by ninhydrin were produced from high concentrations of various dipeptide solutions (Table I).

The strucutres of the products $\left(\mathrm{P}_{1}, \mathrm{P}_{2}, \mathrm{P}_{\mathrm{p}}, \mathrm{P}_{\mathrm{v}}\right.$ and $\mathrm{P}_{\mathrm{L}}$ ) were analyzed by various methods. $\mathrm{P}_{1}$ was identified as Leu-Gly-Leu-Gly from the results of amino acid composition, $\mathrm{N}$-terminal amino acid, C-terminal amino acid, molecular weight, and CPase A digestion of $\mathrm{P}_{1}$.

By the same methods, it can be presumed that the structure of $\mathrm{P}_{2}$ is Leu-(Leu, Leu, Gly, Gly)-Gly. Moreover, the result of CPase A digestion supports the structure (Leu-Gly-LeuGly-Leu-Gly) for $P_{2}$, because the same contents of Gly, Leu, and $P_{1}$ were simultaneously liberated from $\mathrm{P}_{2}$ in the initial stage of the reaction and the liberation of Leu-Gly was also observed later.

From the results of amino acid composition, $\mathrm{N}$-terminal amino acid, C-terminal amino acid, and retention constant of $\mathrm{P}_{\mathrm{p}}$, two possible structures of $P_{p}$ were presumed to be Phe-Val-Phe-Val and Phe-Phe-Val-Val. The structure Phe-Val-Phe-Val for $P_{p}$ was supported by the results of the structural analyses of $\mathrm{P}_{1}$ and $\mathrm{P}_{2}$.

$P_{v}$ is presumed to be a mixture of Val-PheVal-Phe $\left(\mathrm{P}_{\mathbf{v}_{1}}\right)$ and Val-Phe-Val-Phe-Val-Phe
$\left(\mathrm{P}_{\mathrm{v}_{2}}\right)$, from the results of aminoacid composition, $\mathrm{N}$-terminal amino acid, C-terminal amino acid and retention constants of $P_{v}$ :

By the same methods as those for $P_{v}$, it can be presumed that $P_{L}$ is a mixture of Leu-MetLeu-Met $\left(\mathrm{P}_{\mathrm{L}_{1}}\right)$ and Leu-Met-Leu-Met-LeuMet $\left(P_{L_{2}}\right)$ from the results of amino acid composition, N-terminal amino acid, Cterminal amino acid, and retention constants of $P_{L}$. These data are summarized in Table III and Table IV.

These results show that the protease from $S$. cellulosae catalyzes the condensation reaction to produce tetrapeptides and hexapeptides at high concentrations of dipeptides. However, $\alpha$ chymotrypsin did not produce oligopeptides (tetrapeptides or hexapeptides) under the same conditions. Furthermore, there are many reports in which the various proteases, 5,18 ) such as $\alpha$-chymotrypsin, papain, thermolysin, etc., catalyze the condensation reactions from $\mathrm{N}$-protected amino acids (or peptides) and Cprotected amino acids (or peptides). However, there is no report relating to a condensation reaction of $\mathrm{N}$ - and $\mathrm{C}$-unprotected dipeptides by proteases. The present study shows that the protease from $S$. cellulosae is a novel enzyme which catalyzes a condensation reaction of $\mathrm{N}$ and C-unprotected dipeptides.

\section{REFERENCES}

1) M. Bergmann and H. Fraenkel-Conrat, J. Biol. Chem., 124, 321 (1937).

2) K. Inouye, K. Watanabe, K. Morihara, Y. Tochino, T. Kanaya, J. Emura and S. Sakakibara, J. Am. Chem. Soc., 101, 751 (1979).

3) K. Morihara, T. Oka and H. Tsuzuki, Nature, 280, 412 (1979).

4) K. Morihara, T. Oka, H. Tsuzuki, Y. Tochino and T. Kanaya, Biochem. Biophys. Res. Commun., 92, 396 (1980).

5) Y. Isowa, M. Ohmori, M. Sato and K. Mori, Bull. Chem. Soc. Jpn., 50, 2766 (1977).

6) J. Horowitz and F. Haurowitz, Biochim. Biophys. Acta, 33, 231 (1959).

7) M. Fujimaki, M. Yamashita, S. Arai and H. Kato, Agric. Biol. Chem., 34, 1325 (1970).

8) M. Yamashita, S. Arai, S. Tanimoto and M. Fujimaki, Biochim. Biophys. Acta, 358, 105 (1974).

9) T. Muro, Y. Tominaga and S. Okada, Agric. Biol. 
Chem., 48, 1223 (1984).

10) F. Sanger and E. O. P. Thompson, Biochem. J., 53, 253 (1953).

11) M. Brenner, A. Niderwieser and G. Pataki, "ThinLayer Chromatography," ed. by E. Stahl, SpringerVerlag, Berlin, 1969, p. 756.

12) S. Akabori, K. Ohno and K. Narita, Bull. Chem. Soc. Jpn., 25, 214 (1952).

13) H. Fraenkel-Conrat, J. I. Hariss and A. L. Levy, "Methods of Biochemical Analysis," Vol. 2, ed. by D. Glick, Interscience, New York, 1955, p. 359.
14) I. Molnár and C. Horváth, J. Chromatogr., 142, 623 (1977).

15) T. Sasagawa, T. Okuyama and D. C. Teller, J. Chromatogr., 240, 329 (1982).

16) T. Oka and K. Morihara, J. Biochem., 84, 1277 (1978).

17) Y. Isowa, M. Ohmori, T. Ichikawa, H. Kurita, M. Sato and K. Mori, Bull. Chem. Soc. Jpn., 50, 2762 (1977).

18) Y. Isowa, T. Ichikawa and M. Ohmori, Bull. Chem. Soc. Jpn., 51, 271 (1978). 